\title{
Aplikasi Dikili Berbasis Android
}

\section{Safitri $\mathrm{Amu}^{* 1}$ )}

Program Studi D3 Teknik Informatika, Politeknik Gorontalo.Jln, Muchlis Rahim, Botu Pingge, Bone Bolango, Gorontalo, email : fitri.mhs15@ti.poligon.ac.id
Fajar Hermawanto ${ }^{2}$

Program Studi D3 Teknik Informatika, Politeknik Gorontalo, Jln, Muchlis Rahim, Botu Pingge, Bone Bolango, Gorontalo, e-mail: fajar@ poligon.ac.id

\begin{abstract}
Masyarakat Gorontalo sangat menghargai tradisitradisi terutama yang bernuansa islami yang selamanya tetap dilestarikan. Nilai-nilai Islami tersebut telah dikukuhkan melalui semboyan yang menjadi cerminan budaya Gorontalo yang identik dengan Islam yaitu 'adati hula hula'a to sara'a, sara'a hulahula'a to kuru'ani' atau adat bersendi syarak dan syarak bersendi alQuran. Salah satu Tradisi yang bernuansa Islami dan masih dilakukan yaitu Dilili. Dikili merupakan acara dalam rangka memperingati kelahiran Nabi Muhammad SAW. Proses Dikili dilakukan masyarakat dengan mengumandangkan riwayat hidup Nabi Muhammad SAW dimesjid-mesjid melalui pengeras suara. Riwayat tersebut dibacakan menggunakan bahasa Gorontalo yang tertulis dalam huruf hijaiyah. Naskah dikili dibuat dengan tulisan dan diwariskan secara turun temurun, untuk memperbanyak teks tersebut hanya dilakukan melalui foto copy. Sampai saat ini naskah Dikili belum ada yang tercetak secara resmi, atau hanya diwariskan secara turun temurun. Dengan kondisi seperti ini dikhawatirkan suatu saat naskah Dikili akan hilang atau tidak sama dengan aslinya, karena naskah mengalami kerusakan secara fisik, kerusakan tersebut sangat memungkinkan dapat menghilangkan sebagian atau keseluruhan teks aslinya. Dengan memperhatikan beberapa masalah tersebut maka diperlukan adanya dokumentasi yang lebih efisien, fleksibel dan tahan lama. Dokumentasi yang di buat harus dapat dibaca kembali dengan mudah, mudah di dapatkan, di distribusikan, tanpa harus terbatas dengan teknologi yang ada saat ini, teknologi yang sangat memungkinkan dan mudah di dapatkan oleh masyarakat yaitu smartphone android. Hasil akhir dari aplikasi Dikili dapat mempermudah masyarakat untuk mengetahui bacaan dan sudah bisa digunakan dan berhasil menarik peminat.
\end{abstract}

Kata kunci : Gorontalo, Dikili, Android.

\section{PENDAHULUAN}

Bangsa Indonesia merupakan bangsa yang kaya akan kebudayaan. Hampir setiap daerah diseluruh Indonesia memiliki adat, bahasa dan kebiasaan masing-masing, beberapa di antaranya sangat terkenal di kancah nasional maupun internasional. Hal ini menjadi daya tarik tersendiri bagi warga negara Negara lain untuk berkunjung ke Indonesia.. Gorontalo merupakan salah satu provinsi di bagian utara pulau Sulawesi. Provinsi Gorontalo adalah sebuah kota yang mewarisi keindahan budaya nenek moyang yang begitu mempesona. Budaya atau kebiasaan-kebiasaan hidup masyarakat daerah Gorontalo saat ini telah mengalami perubahan dan pergeseran mengikuti perkembangan jaman.

Dikili merupakan salah satu tradisi yang masih dilakukan oleh masyarakat gorontalo dan pelaksanaannya setiap bulan Rabiul Awal. Dikili dilaksanakan untuk mengiringi Maulidnabi yaitu tradisi kurang lebih 17 jam, dimulai kira-kira dari jam 8 malam sampai jam 9 pagi. memperingati kelahiran Nabi Muhammad SAW yang diadakan di masjid. Pelaku Dikili sekitar 60 sampai 200 orang yang di dominasi oleh kaum perempuan. Dikili dilagukan selama

Diceritakan orang dari pada nabi SAW bawasanya nabi bersabda adalah aku ini suatu cahaya Antara hadratullahi taala sebelum bawasanya dijadikan aleh allahu taala akan nabiyullah adam dengan dua ribu tahun lamanya mengucap tasbih cahaya itu dan mengucap tasbih segala malaikat sebab cahaya itu. Maka tataka dijadikan oleh allahu taala akan nabiyullah adam maka diturunkan akan daku oleh allahu taala dalam sulbi nabiyullah adam kepada bumi dan ditinggalkan akan daku didalam bantera pada sulbi nabiyullah Ibrahim halilullah. Pada ketika itu ia dibuangkan orang kafir kedalam api. Dan senatiasa dipindhkan dari pada segala sulbi yang suci lagi sehingga dikeluarkan akan daku oleh allahu taala dari pada Antara ibu bapaku dan tiada bertemu keduanya atas perbuatan yang jahat sekali kali(Tin Olii). Asal usul Dikili yaitu diambil dari kitab dalam alquran, ilmu syariat Nabi dilahirkan pada hakikatnya Nabi tidak diperanakan hanya saja diperintahkan untuk memperingati hari kelahiran atau hari kebangkitan Nabi, yang membedakan dari masing-masing isi yaitu nada atau lagunya berganitan, tujuan dari dikili untuk membesarkan kelahiran Nabi Muhammad SAW dengan lafalnya dengan hukum aturan harus aktif dan dengan dibarengi dengan adat dan tempat duduk harus sesuai dengan tempat yang disediakan. (Pak Imam $\mathrm{Hj}$. Hamzah Lihawa. Imam kec. Telaga Jaya) pelatih semua tradisi Gorontalo.

Dokumen tersebut hanya dituliskan menggunakan tulisan tangan pada sebuah buku yang diberikan secara turun temurun, disamping itu belum adanya teks Dikilil yang dicetak secara resmi melalui penerbit percetakan. Untuk memperbanyak teks tersebut masyarakat hanya memfotocopy dari teks yang sudah ada. Ada saatnya hasil fotocopy tidak akan sama dengan teks aslinya, seiring waktu teks asli akan mengalami kerusakan karena hanya tertulis dengan lembar kertas.

Dengan memperhatikan beberapa masalah tersebut maka diperlukan adanya dokumentasi yang lebih efisien, fleksibel dan tahan lama. Dokumentasi yang dibuat harus dapat dibaca 
kembali dengan mudah, mudah didapatkan, di distribusikan, tanpa harus terbatas dengan teknologi yang ada saat ini, teknologiyang sangat memungkinkan dan mudah didapatkan oleh masyarakat yaitu smartphone android. Android merupakan salah satu sistem operasi open source atau terbuka, menjadikan manusia paham dengan teknologi maka kini Handphone Android adalah handphone dengan sisitem operasi pintar yang memiliki desain tampilan teknologi yang canggih. Manusia akan lebih mudah menemukan berbagai teknologi lewat Handphone Android dan memiliki rasa ingin tentang android yang membuat manusia lebih paham dengan teknologi mada kini.Berdasarkan permasalahan yang ada maka dapat dibuat sebuah Aplikasi yaitu "Aplikasi Dikili Berbasis Android"

\section{II.METODE PENELITIAN}

Pada bagian ini menjelaskan mengenai gambaran umum pada Aplikasi Dikili Berbasis Android.

\subsection{Gambaran umum Aplikasi}

Dalam gambaran umum aplikasi ini terdapat beberapa tampilan yang mana pengguna akan membuka aplikasi yang sudah ada pada smartphone yaitu aplikasi Dikili, di dalam aplikasi Dikili ini terdapat beberapa menu utama salah satunya yaitu menu daftar Dikili, dalam menu daftar Dikili ada beberapa sub yang akan kita pilih nantinya di tampilan ini kita akan membaca hasil dari tampilan yang sudah kita pilih sebelumnya.

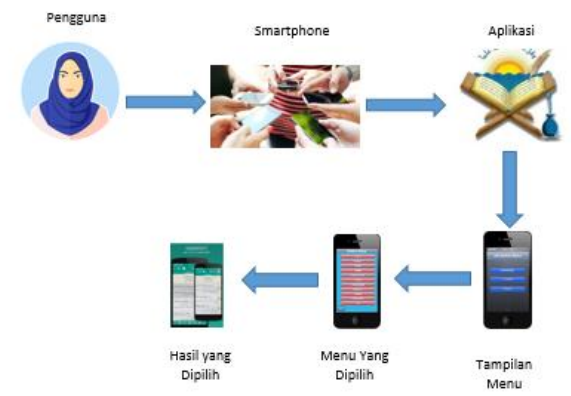

Gambar 1. Gambaran Umum yang diusulkan

\subsection{Use Case}

Use case bekerja dengan cara mendeskripsikan jenis interaksi antara user(aktor) dengan sistemnya sendiri melalui sebuah cerita bagaimana sebuah sistem dipakai. Gambar use case yaitu menampilkan tiga use case yaitu menu dikili, menu sejarah dan menu tentang yang mana di menu dikili memiliki use case turunan yaitu asala, bisahari, tanaka, wulida, hasala, kasidu, pimisili, alhmad ulillah, asraka, palakamlahu, pataraku, ta amali, man misilu, yamaulida, salal ila, ta allawubina, habibi dan doa.

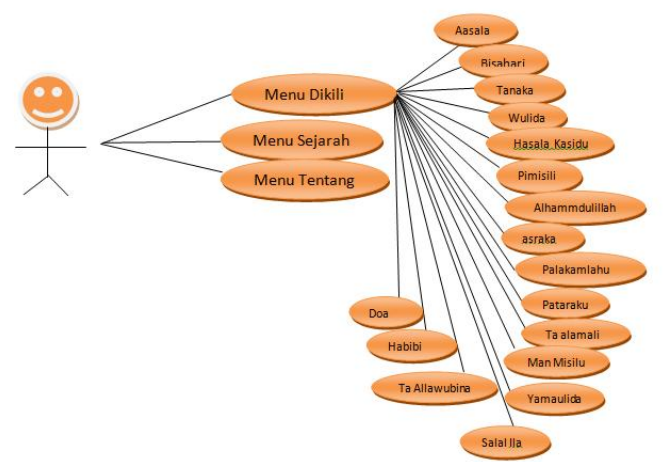

Gambar 2. Use case Diagram

\subsection{Activity Diagram}

Activity diagram memodelkan alur kerja (workflow) sebuah proses bisnis dan urutan aktivitas dalam suatu proses. Diagram ini sangat mirip dengan sebuah flowchart karena kita dapat memodelkan sebuah alur kerja dari satu aktifitas ke aktifitas lainnya atau dari satu aktifitas kedalam keadaan sesaat (state). Sering kali bermanfaat bila kitamembuat sebuah activity diagram terlebih dahulu dalam memodelkan sebuah proses untuk membantu kita memahami proses secara keseluruhan. Activity diagram juga sangat berguna ketika kita ingin menggambarkan perilaku pararel atau menjelaskan bagaimana perilaku dalam berbagai use case berinteraksi.

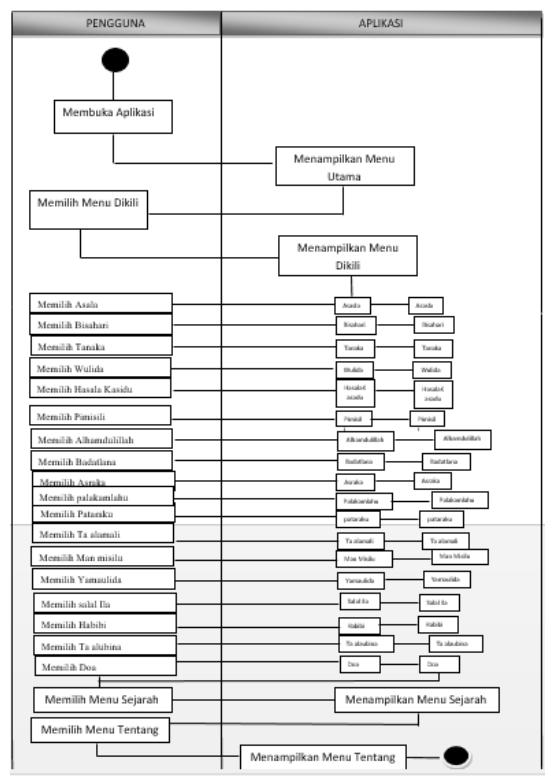

Gambar 3. Activity Diagram

\subsection{Alat dan Bahan \\ 1. Laptop/PC \\ 2. Smartphone \\ 3. photoshop \\ 4. Java \\ 5. Eclipse}




\section{AndroidSDK (Software Development Kit)}

\section{HASIL DAN PEMBAHASAN}

\subsection{Menu Utama}

Halaman utama ini merupakan halaman untuk pengelolaa $\mathrm{n}$ sistem. Dalam implementasinya halaman sistem dibagi sesuai dengan manfaat masing-masing yang berbeda dan hak akses yang berbeda pula. Dalam halaman utama ini terdapat tiga bagian Menu yaitu:

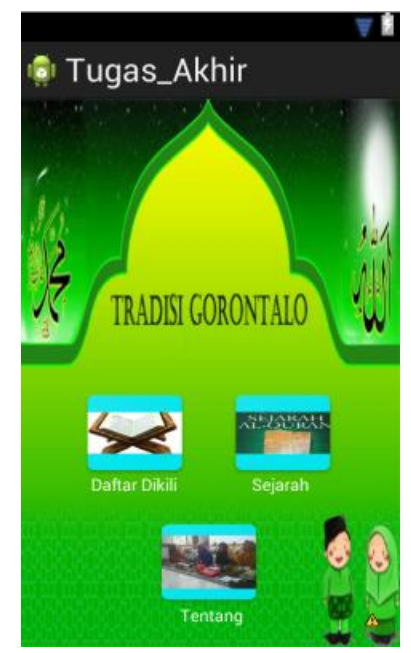

Gambar 4. Halaman Utama

Menu Daftar Dikili yaitu untuk melihat daftar dikili, Menu Sejarah untuk menulisakan sejarah tentang terbentuknya tradisi MauidNabi yang ada di Gorontalo, Menu Tentang Menu ini menulisakn tentang bagaimana cara menggunakan Aplikasi Dikili.

\subsection{Menu Daftar Dikili}

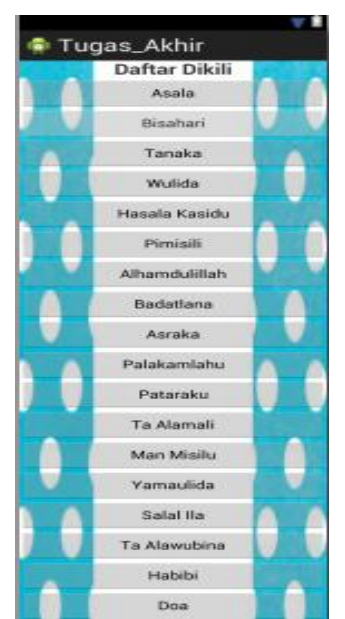

Gambar 5. Menu Daftar Dikili

Menu Daftar Dikili merupakan halaman kedua dari yang akan terbuka ketika kita mengklik menu Daftar dikili. Halaman ini akan menampilakan tentang menu apa saja yang ada di daftar dikili yaitu Asala, Bisahari, Tanaka, Wulida, Hasala, Pimisili, Alhamdulillah, Badatlana, Asyraka, Palakamlahu, Pataraku, Ta-alamali, Man-misilu, Yamaulida, Salal-ila, Ta-alawubina, Habibi dan Doa.

Di halaman daftar dikili ini pengguna bisa melihat daftar dikili yang akan di baca serta bisa mendengar nada dari bacaan tersebut.

\subsection{Menu Asala}

Menu Asala menceritakan bahwasanya Dengan nama allah jiwa aku memulai membaca kitab ini yang amat murah didalam negri dunia lagi amat mengasihani hambanya yang mu'min di dalam negri akhirat. Segala puji-pujian bagi allah yang memuliakan hambanya dan ialah yang mempunyai makami yang tinggi dan disempurnakan oleh allahu taala bahagia akan dia sebab memuliakan akan kejadian Rasulillah SAW itu.

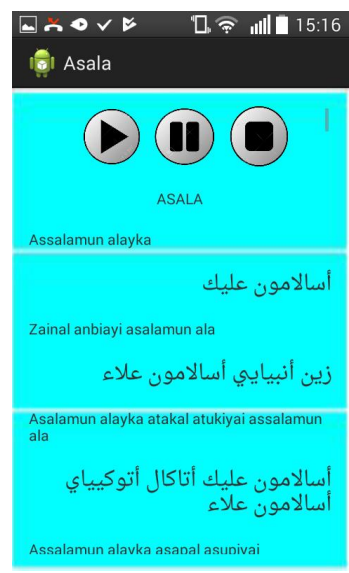

Gambar 6. Menu Asala

3.4. Menu Bisahari

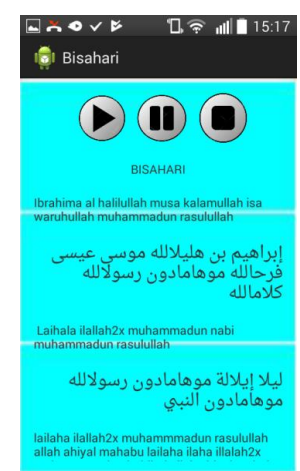

Gambar 7. Menu Bisahari

Menu Bisahari menceritakan hai nabiyullah bahwa sanya kami dititahkan engkau akan naik saksi dan menceritahkan surge dan neraka; artinya naik saksi bagi segala rasulullah SAW dengan menyampaikan parmanullahi taala dan menceritakan bagi barang siapa membawa iman akan dianugrahi allah taala surga dan menakuti bagi barang siapa 
yang mendustakan akan dimasukan dalam api neraka. Dan menyuruhlah segala rasulullah SAW kepada mentauhidikan allahu taala dan berbuat taat akan allahu taala dengan penjuru allahu taala itu.

\subsection{Menu Wulida}

Menu Wulida menceritakan bahwasanya Dikata orang tatakala dikehenadaki oleh allah taala akan menjahirikan sebaik-baik mahluknya Nabi Muhammad SAW maka oleh allah taala dari pada jibril akan tempat kubur rasulullah SAW, maka diambil oleh jibril akan tanah itu kemudian maka ditawapkan akan tanah itu kedalam sorga yang bernama jannatun nain. Dan disalamkan akan tanah itu didalam sungai yang bernama TASNIM, dan dibawahnya akan tanah itu ke hadratullahi taala yang amat tinggi lagi maha besar dan mengalir-ngalirlah penuh tanah itu maka dijadikan oleh allah taala dari pada peluh tanah itu akan cahaya nabi Muhammad SAW yang besar-besar.

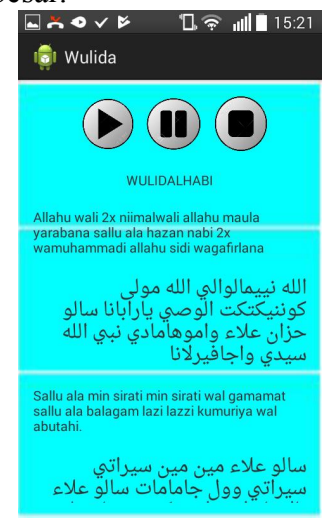

Gambar 8. Menu wulidalhabi

3.6. Menu Hasala

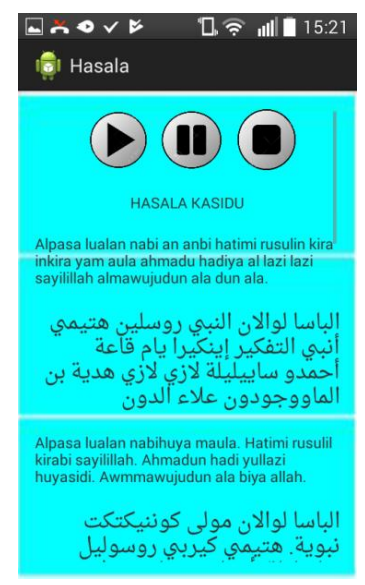

Gambar 9. Menu Hasala

Menu Hasalakasidu menceritakan bahwasanya Maka tatakala sangatlah baginya hendak terhujung nipasnya pada hal tiada diketahui akan dia oleh seorang dari pada manusia. Maka mendadakan akan kedua tapak tangan padahal mengadukan dirinya kepada tuhan yang mengetahui segala rahasianya dan kehendaknya. Maka datanglah asia istri fir'aun dan sitti Maryam dan anak-anak bidadari, yang elok rupanya bahwasanya telah teranglah dari pada keelokan sekalian mereka itu akan segala tempat,maka hilanglah dari pada sitti aminah barang yang diperoleh dari pada percintaan.

\subsection{Menu Pimisili}

Menu Pimisili menceritakan Maka beranaklah sitti aminah akan nabi muhammadin SAW yaitu bercila kedua matanya lagi terhitam. Maka disambut akan dia oleh segala malaikat maka ditawapkan akan dia dari pada segala tempat dan memberi tahu akan dia dari pada segala isi tujuh patla langit dan bumi. Dan kepada segala isi laut. Maka dikembalikan oleh mereka itu dengan kelebihan atas kedua negri kepada ibu bapaknya sitti aminah. Dan terlebih segera dari pada mata. Maka berkelipanlah dari pada segala alam panji-panji pengetahuanya. Maka lanjutlah segala yang diceritakan orang bagi kejadian rasulullahi SAW. Dan sentosalah dan hilanglah segala duka cita dan diperolehlah dan segala kekayaan dan disampaikan segala yang dikhendaki kita. Maka suka citalah hati manusia dan diampunilah segala dosa dan tertutuplah segala kecelaan dengan berkat nabi muhammadin SAW yang yang dikasih-kasihani oleh allah azzawadjallah dan heninglah segala ketika dan berkasihkasihanilah mereka itu sebab melihat akan nabi muhammadin SAW. Maka sukacitalah segala hamba allahu taala.

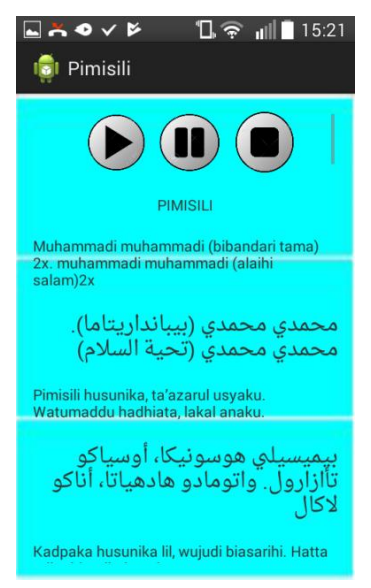

Gambar 10. Menu Pimisili

\subsection{Menu Alhamdulillah}

Menu Alhamdulillah menceritakan Maka terbitlah bulan yang amat menerangi akan segala alam. Maka indah-indah keelokanya dari pada terbitlah bulan dan maha indah-indah cahayanyadan amat elok parasnya dari pada segala keelokanya, dan terlalu sekali manisnya. Maka tatakala dihamilkan oleh sitti aminah akan nabi SAW maka datanglah kepada sitti aminah nabiyullah adam AS dan disampaikan akan dia dengan kebaikan dan berdirilah nabiyullah nuuh pada pintu sitti aminah. Maka berseru-serulah akan dia dan datanglah pula nabiyullah ibrahimal halilullah dan 
diceritakannya kepada sitti aminah barang itu kepada nabiyullah musa kalamullah. Dan memberi salam akan dia dan memuji-muji akan dia. Dan maka tiap-tiap yang demikian itu kaena kejadian dengan diperanakan ini yang telah bercahayacahaya dengan dia segala bumi dan segala isinya. Maka datanglah segala ungggas dari pada sarangnya dan dari pada temapat dan keluarlah anak-anak bidadari dan atas segala jenis pakaiannya yang indah-indah dan kesukaan yang ada di dalam surga. Dan berseru serulah mereka itu cahaya api ini yang telah memenuhi segala tempat dengan perhiasanya. Maka berkata djibrail bahwasanya telah diperanakan akan yang terlebih dari pada yang lain dari pada manusia.

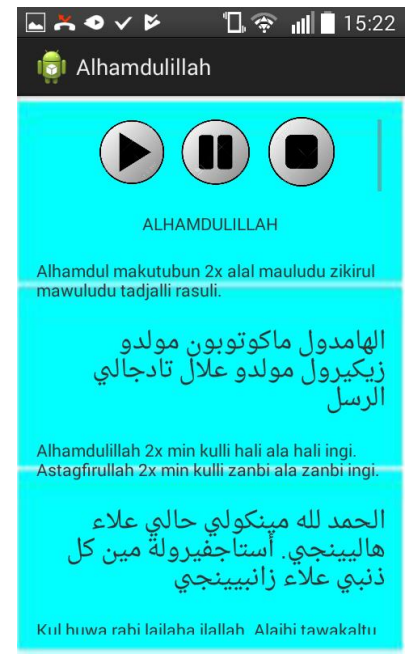

Gambar 11. Menu Alhamdulillah

3.9. Menu Badatlana

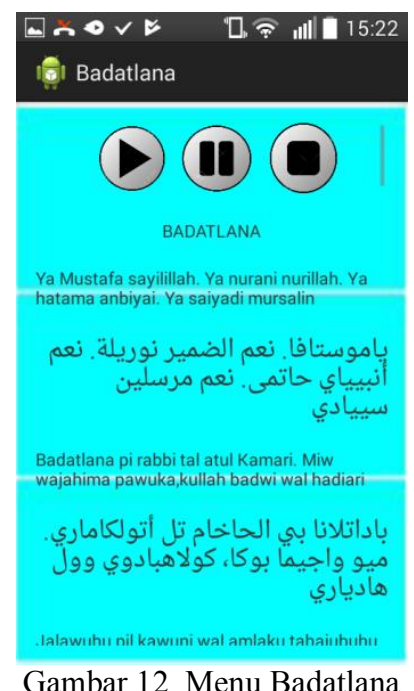

Menu Badatlana menceritakan Maka tatkala hampirilah dewasa masa jadi nabi muhammadin SAW yang maha mulia lagi maha besar dan hampirilah pengetahuannya yang maha mulia lagi maha besar dan berseru-serulah dengan nyaring suaranya dan memberi isyarat dengan disampainyanya yang amat baik maka sekalian isi bumi seakan-akan berkata karena engkau menjadi rahmat dan tiada kami akan menyerahkan dikau hai Muhammad melainkan karena engkau menjadi rahmat dari pada sekalian alam. Maka adalah tatkala itu dikelubungi oleh segala malaikat akan ibunya sitti aminah dan didindingnya dengan sayapnya dari pada mata orang celaka. Maka duduklah dari pada pihak kananya mikaliu dan Antara hadapanya jibril dan bagi segala mereka itu berdengungdengung mengucap tasbih dan takdis dan tahlil bagi tuhan malikil jalil.

\subsection{Menu Asyraka}

Menu Asyraka menceritakan Dan datanglah anak-anak bidadari kepada bundanya sitti aminah. Dan bahwasanya sitti amninah sentosalah dari pada segala yang ditakutinyadan ialah ganti dari pada bundanya dan segala manusia. Dan disampanannya oleh segala anak-anak bidadari dengan berbahagialah yang tidak berkesudahan. Bercahayalah bulan dan cemerlanglah cahayanabi Muhammad SAW maka kesukaranlah kepada siti aminah dan adalah hamilnya itu maka kersalah sakitnya. Maka beranakah sitti aminah akan nabi Muhammad SAW seolah-olah nabijjulah itu seperti bulan purnama empat belas hari bulan.

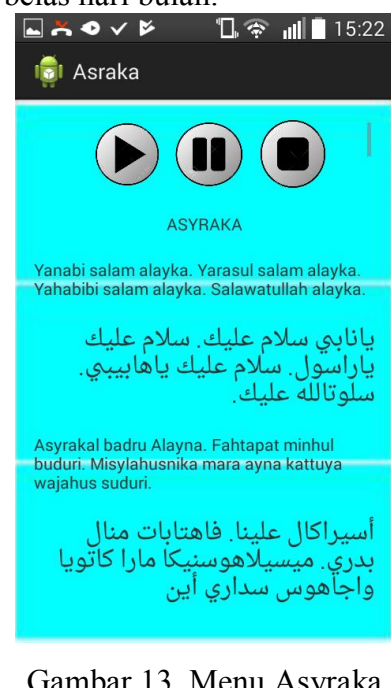

\subsection{Menu Palakamlahu}

Menu Palakamlahu menceritakan Tintahu louma bo timihulala tinelo nabi Muhammad SAW todelomo dunia. Wawu ma lolametolomao nabiyullah lotidudupapa totalu lo allahu taala molanggata wau boli uda-udaa. Wawu diyaluwo ta pilopowali liyo mayi ta tamihumayawa woliyo. Totonulalo ta pilotutu tamomolomao leto ma lotamaya mola nabiyullah lo tutunuliyo ngongo ode hulunga tuwuto uma lopotuwawu mola lo allahu taala molamahe wawu boli molanggata wawu touma pilotutu liyo mayi nabiyullah yito ma putu-putulo mayi wolodiyo wawu ma isi-isilamulo mayi wawu mayideyidetolo mayi lo huta lo makkah bihu mato lio mohu-mohuwaliya, wawu mahuli-huli mayi loumonu laba-laba lotutu motungengeta boliyo. Wawu uhelumuwalayi todungito 
rasullulah yito bo tinela mabo timihulala wawu ma loobangolo mao malihe lo olongiya lo kusra mao to huta lolipu lo samu.

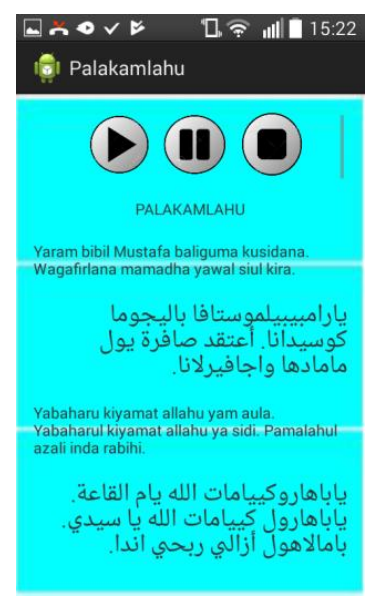

\subsection{Menu Ta Alamali}

Gambar 14. Menu Palakamlahu

Menu Ta Alamali menceritakan Lotombilu tilo Halima wawu mahilama liyo mao nabiyullah wawu madilelo liyo mao ode bele lobui tangguliyo hubalu tauwa liyo dudulaa. Teto malolohubulo mola tonula bui ngopohiya, wolo uma lopipitangolo bui biyito. Wawu tilohalimah yito bo ohilawo ma mopodila oli nabiyullah to hajral aswad, dilolotonga louma loheyilo mayi hajral aswad boyito to dutuwa liyo, dilolotonga louma lodudunggaya wolo baya lo rasulullah SAW. Wawu tou tilo halimah mayi ledungga ode to talolai liyo mayilungguli liyo mao totonula uma hemowali mayi oliyo boyito. Teto bolo umawamao lo talolai liyo uwaliyo dila mahepolele umayi olemu taukikinga bitiye tama pilongohiya liyomayi ilo mata olanto dudulota tumbao bo hamalo mayi ta ukikinga botiye wawu madelontolo.

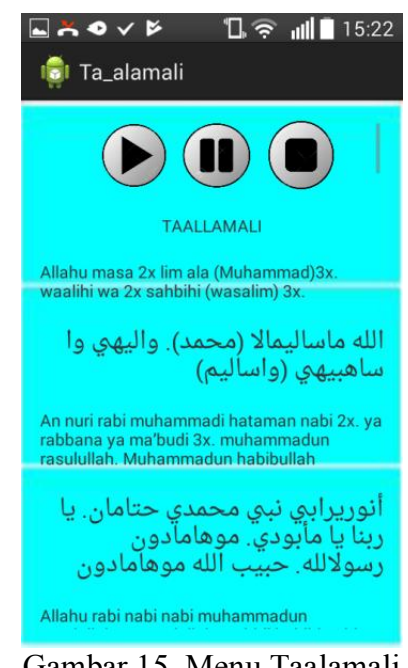

\subsection{Menu Man Misilu}

Menu Man Misilu menceritakanLotombilu tilo halimah uwaliyo ma layi-layitolo ponu lo allahu taala doula oliyo wolo tonulola umopiyo wolo tonulola ilomata lo nabiyullah SAW.
Tomomoliyo mao tutuliyotutu todulahe tuwawu nabiyullah yito mayilumuwalao wolo wutatiyo ngotilutuwa waliyo ta tanggula te dhumurah wawu bomao molami mayi batade totihedu bele li mongoliyo. Dipo wololo hihewoliyo debolo mateteteteayi te dhumura wolou mabo tamu-tamu wayatayi lo bayaliyo wawu maiibode oliloliyo tilo halimah uwaliyo wu nana halimah mao lolohepo mayi wutato lowatiya ti muhammadi madiyaluwo tiyo wawu dila bomao lonto bento tiyo mayilate lou pilate lotawu karna tutuliyo tutu oodito mayililunga lo allahu taala doula oliyo.

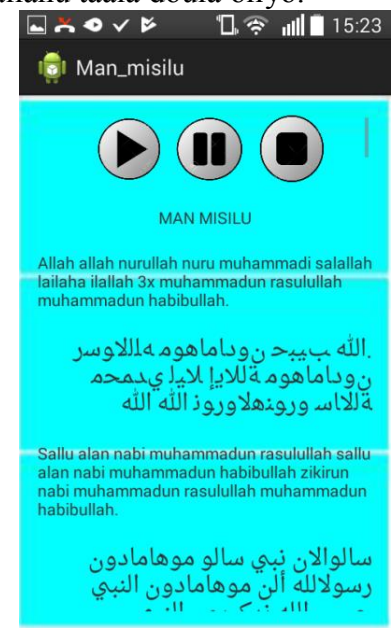

Gambar 16. Menu Man Minsilu

3.14. Menu Yamaulida

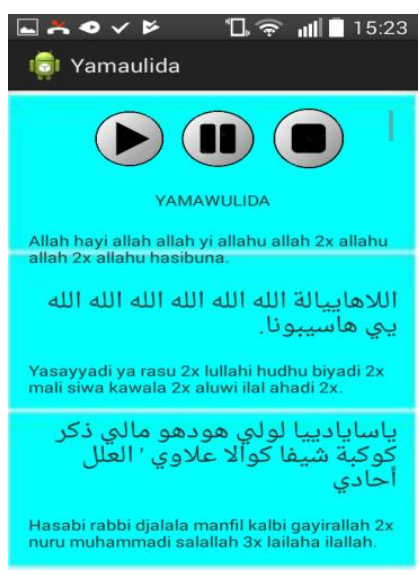

Gambar 17. Menu Yamaulida

Menu Yamaulida menceritakan wawu matilanggula liyo mayi tiyo lo allahu taala eya lo tonulola alamu moaamilala, de uwitoyio tanggula muhammadi de boliliyomao ta dewowama doula tolakuliyo laba-labalo tutu molamahe. Wawu de allah taala ta motota lou mao piloi pomotaaliyo tuwango deheloliyo boyito dila bo karna dei bo tutuliyo tutu timongoliyo malaikati boyito bo maloduhenga umo lamahe. Wawu tiyo-tiyolo nabi ma pilongilabotiyo mayi to nabi moaamilala ou daa liyo wolo hikimati liyo wolo tonulola polo utiya loilo untungiliyo wawu uda-udaa tutu eetiliyo wolo obuheliliyo wonu deu dila tiyo

ISSN : 2502-1613 
dila pilopowali mayi lo allahu taala tonulola malaikati wawu dila lowali heliliya, wawu dila yilumuneta tinelo mota lo dulahu wawu hulala. Wawu tiyo malolao mola loli biluloa modioloma wawu boli montotoyooma tuudu uma pilidudutiyo mayi lou matilunggula mola ode biluloa molanggata wawu boli uda-udaa wawu molamahe.

\subsection{Menu Salal Ila}

Menu Salal Ila menceritakan Lotombilu ti abdul wahidi walaiyo li ismaila, uwaliyo woluwo mao to lipu lo masiri tolalai ngota wambao hemoimolohutuwa mawuludu to nabi muhammadi SAW moti-motiidu tawunu. Wawu woluwo olo talolai ngota yahudi totitihediyo lo bele li mongoliyo boyito. Lotombilu dile lota yahudi uwaliyo naolo malowolo uhepo hutuwo lota isilamu ngongotihede wolanto botiye, mabolo hemo muwa-muwayade harataliyo to hulala botiya. Bolo uwamao lo tolalai liyo uwaliyo wonu deu dipo otawamu uhemoohutowa oliyo uoodito boyito karna hemopoudaa mola ta nabi liyo wawu upilotutuwa liyo to nabi limongoliyo to tawunu botiye. Tohuhama lou he mopowengahe mola ti nabi limongoliyo. Lotambilu taohuuwo lo wungguli, uwaliyo bele boyito. Poli lotambilu dilelota yahudi tota lolailiyo uwaliyo naolo delomo huta tiyo boyito wonu deu mota poloiyau.

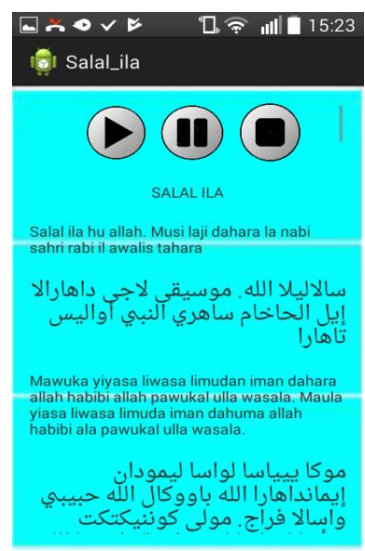

Gambar 18. Menu Salal Ila

3.16. Menu Ta Alawubina

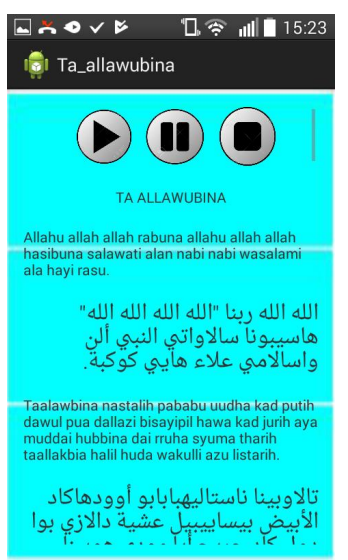

Gambar 19. Menu Ta Alawubina
Menu Ta Alawubina menceritakan Lotombilu dile lota yahudi uwaliyo tutuliyo tutu ito-itolo eya nabi laba-labalo tutu molamahe wawu boli uda-udaa wawu boli molanggata uilowaliya lota eya, wawu bolo meyalo tita lotita tamo titi hulode tou llowaliya lo ito eya, yiyo bo popowuduwalo mayi tutunu lo ito eya alihu ma ayita lowatiya wawu watiya ma timihila sakusi tutuliyo tutu diyalu eya ngopohiya ta tubola tuha-tuhata debolo allahu taala tazati wajibal wujudi mustahakul alamu ma'budu bihakikaya iftikari. Deboliliyomao tiyo eya ta wajibu wawu ta lopowali mayi lo alamu moaamilala wawu tutu liyo tutu ito-itolo nabi ilahula lo allahu taala.

\subsection{Menu Habibi}

Menu Habibi menceritakan Tomomolliliyo mao leto dila lota yahudi boyito ma lo najaralo mola ode allahu taala to delomo rahasia liyo wawu maohilawo mohutu mawuludu lo nabi SAW, yiyo tou madimodupa mola dile lota yahudi boyito mahemo po sada-sadaka olota moaamila la hiambuwa boyito, bolo meyalo uoodito boyito huhutu lo mawuluddu lo nabi SAW karena mayi laba-labalo tutu hilaliyo tuudu utiyo ma tumuwoto agama isilamu, wolo syukuruliyo totutulu hiyo boyito yiyo teto mame ilontonga lo talolai liyo tiyo boyito mahemopodatatou todelomo hilaliyo wolo eetiliyo. Teto ma lolinggalabe talolai liyo tou loonto mao huhutu lo dole liyo boyito. Yiyo ma loloiya mao dile lota yahudi boyito uwaliyo deloma ontongamu wau botiya ma todelomo huhutu labalabalo tutu mopiyohe botiya.

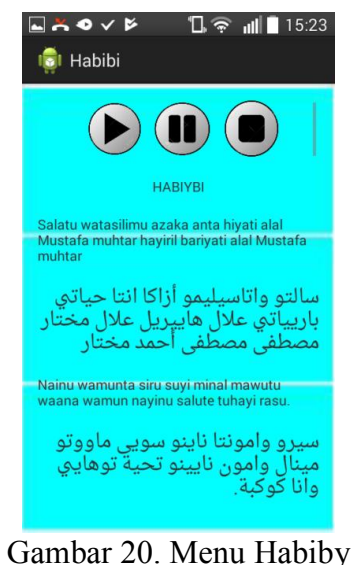

3.18. Menu Doa

Gambar 20. Menu Habiby

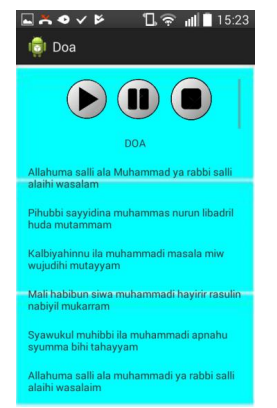

Gambar 21. Menu Doa

ISSN : 2502-1613 
Menu Doa merupakan halaman ke tujuh dari yang akan terbuka setelah kita memilih masing-masing daftar dikili menu yang ini yaitu menu doa, doa ini adalah daftar ke delapan belas dari daftar dikili halaman ini akan menampilakan bacaan huruf hijaiyah (arab), hijaiyah (latin ) beserta bahasa indonesia, di setiap bacaan pasti berbeda nada pengucapan. Halaman ini memiliki tiga button yaitu button putar, button pause dan button stop dalam button ini berfungsi untuk mendengar suara.

\subsection{Menu Tanaka}

Menu Tanaka menceritakan bahwasanya Dan diceritakan dari pada jazidi anak Abdullah cucu wahab ia mendengar pada saudara bapaknya yang perempuan, berkata ia adalah kami bahwasanya sitti aminah tatakala ia mengandung akan rasulullah SAW adalah berkata ia tiada hamba ketahui bahwa diri hamba mengandung. Dan tiada hamba peroleh karenanya mengandungi akan nabi SAW dan tiada berat seperti yang diperoleh segala perempuan melainkan bahwasanya tersadar hamba dan terangkat dewasa haid hamba. Maka datang kepada hamba suatu suara. Dan adalah hamba tatkala itu Antara tidur dan juga. Maka berkata suara itu, adakah engkau ketahui hai sitti aminah bahwasanya engkau ini telah hamil. Maka seolaholah hamba berata. Tiada hamba ketahui maka berkata suara itu bahwa engkau ini telah hamil akan seorang penghulu segala umat ini.

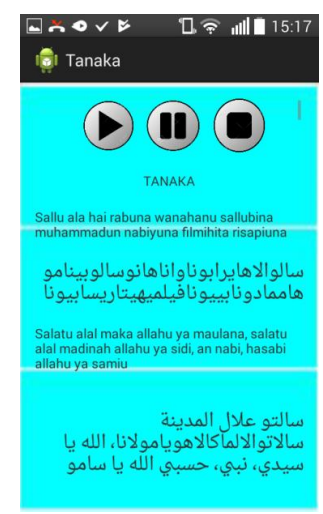

Gambar 22. Menu Tanaka

3.20. Menu Sejarah

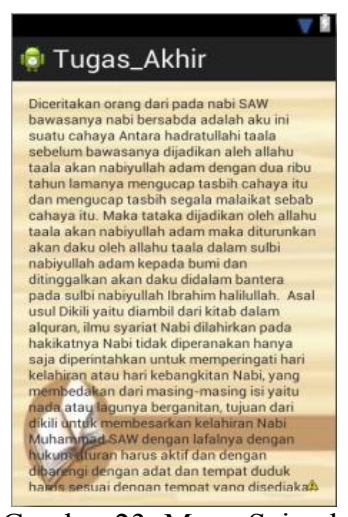

Gambar 23. Menu Sejarah
Menu sejarah merupakan menu yang akan menceritakan sejarah terbentuk nya tradisi Dikili, dengan ini Pengguna bisa mengetahui sejarah MaulidNabi.

3.21. Menu Tentang

Menu tentang merupakan menu yang menceritakan tentang tradisi Dikili.

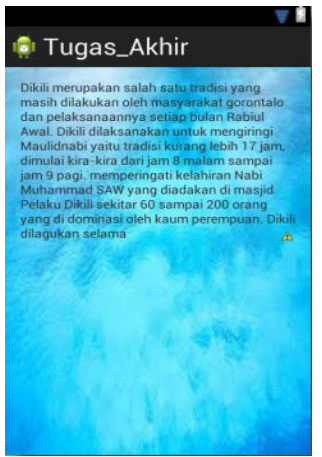

Gambar 24. menu Tentang

\section{IV.PENUTUP}

Berdasarkan hasil evaluasi dan implementasi yang telah dilakukan penulis, maka penulis dapat menyimpulkan bahwa: Aplikasi Dikili ini dapat mempermudah proses pengetahuan bagi masyarakat dalam belajar membaca huruf arab dan bisa membantu masyarakat dalam mengucapkan bacaan dengan benar agar bisa menarik banyak peminat untuk mempelajari tradisi Dikili. Hal ini membuat banyak peminat untuk belajar.

\section{SARAN}

Dari analisis pengujian yang telah dilakukan penulis menyadari bahwa aplikasi ini perlu pemahaman dalam membuat huruf arab dengan benar dan lebih teliti unuk membaca huruf arab.

\section{DAFTAR PUSTAKA}

[1] J.Ilmiah, I. Komputa, M.Y. Herdiansyah, I. Afrianto, and J.D Bandung, " Pembangunan Aplikasi Bantu Dalam Menghafal Al-Qur'an Berbasis Mobile “Teknik Informatika (KOMPUTA), vol. 2, no.2,2013.

[2] J. S. Informasi, F. Sains, and D. A. N. Teknologi, aplikasi indekssains dan teknologi dalam alqur'an berbasis android.2017.

[3] A. Pengenalan and D. A. N. Pembelajaran, "jurnal SCRIPT Vol. 1 No. 1 Desember 2013 ISSN : 23386304,” vol 1, no 1, pp. 78-88,2013.

[4] E. Bash, " Pembangunan Sistem Aplikasi Penyewaan Mobil Berbasis Android Studi Kasus di CV Abu Sulaiman RENTCAR", PhD Propos., vol. 1, pp. 118,2015. 
[5] M. D. I Gorontalo, “ Tradisi sastra dikili dalam pelaksanaan upacara adat maulidan di gorontalo, “vol. 16, no. 1, pp. 1-21.

[6] D. Permatasari and A. Falah, " Aplikasi pembelajaran Ilmu Tajwid Berbasis Android (Studi kasus: Madrasah Ar-Rahman Bandung," J. Teknol. Dan inf., 2015. 